\title{
DIAGNOSTIC IMPORTANCE OF CYTOLOGY IN GIANT CELL CARCINOMA OF LUNG
}

\author{
Shuchismita1, Guddi Rani Singh ${ }^{2}$, Atul Gupta ${ }^{3}$, Deepak Kumar ${ }^{4}$, Krishna Kumar Singh ${ }^{5}$
}

${ }^{1}$ Senior Resident, Department of Pathology, AIIMS, Patna.

${ }^{2}$ Senior Resident, Department of Pathology, IGIMS, Patna.

${ }^{3}$ Professor, Department of Pathology, S. N. Medical College, Agra.

${ }^{4}$ Senior Resident, Department of Radiology, AIIMS, Patna.

${ }_{5}^{5}$ Assistant Professor, Department of Psychiatry, IGIMS, Patna.

\section{ABSTRACT}

\section{BACKGROUND}

Giant Cell carcinoma is a variant of Sarcomatoid carcinoma which occurs at a younger age and predominantly in smoker males. Metastasis and wide spread extension is common by the time of diagnosis and is associated with a poor outcome. Fine needle aspiration cytology (FNAC) has a great role in diagnosing Giant cell carcinoma which are not amenable for surgical excision and early diagnosis by FNAC will greatly influence of the survival rate as treatment can be started immediately. We report a case of Giant Cell Carcinoma diagnosed by FNAC in a 55 yrs. male who presented with lung mass in the periphery of right lower lobe associated with overlying rib destruction.

\section{KEYWORDS}

Giant Cell Carcinoma, Sarcomatoid, Carcinoma, FNAC.

HOW TO CITE THIS ARTICLE: Shuchismita, Singh GR, Gupta A, et al. Diagnostic importance of cytology in giant cell carcinoma of lung. J. Evolution Med. Dent. Sci. 2017;6(10):810-812, DOI: 10.14260/Jemds/2017/176

\section{BACKGROUND}

The 2015 World Health Organization (WHO) Classification of Tumours of the Lung, Pleura, Thymus and Heart has just been published and there are no major changes in the terminology or diagnostic criteria for these tumours since the 2004 Classification. ${ }^{1}$ Giant cell carcinoma lung (GCCL) is a rare histological type of non-small cell lung cancer (NSCLC), first described by Nash and Stout in 1958. It shows male predominance and incidence of pure GCCL comprises 0.1$0.4 \%$ of all lung cancers. ${ }^{2}$ It is a very aggressive tumor with poor outcome. Giant cell carcinomas have been reported in a significantly younger population than all non-small cell carcinomas considered as a group. ${ }^{3}$ GCCL are consistently diagnosed much more frequently in the lung periphery. ${ }^{3}$ GCCL is now classified as one of the subtypes of sarcomatoid carcinoma of the lung which has a differentiation neither towards squamous cell carcinoma nor towards adenocarcinoma. Cytological diagnosis of Giant Cell Carcinoma has a great effect on the patient care and outcome as treatment can be started early because GCCL is not routinely treated surgically, because, it is metastatic at the time of diagnosis. FNA smears show anaplastic and pleomorphic giant cells, ranging from multinucleated forms to large mononuclear forms. This neoplasm has been shown to have dismal response to chemotherapy when compared to other non-small cell lung carcinomas. ${ }^{4}$

Financial or Other, Competing Interest: None.

Submission 23-12-2016, Peer Review 15-01-2017,

Acceptance 22-01-2017, Published 02-02-2017.

Corresponding Author:

Dr. Guddi Rani Singh,

Senior Resident,

Department of Pathology,

IGIMS,

Patna.

E-mail: drgrsingh@gmail.com

DOI: $10.14260 /$ jemds $/ 2017 / 176$

\section{(c) $(1)$}

\section{CASE REPORT}

A 55-year-old gentleman, known chronic smoker, presented with cough and haemoptysis. Plain computed tomography (CT) scan of chest was done. CT findings showed a mass in periphery of right lower lobe lung. The mass was seen infiltrating the overlying rib (Fig. 1). The patient underwent CT guided fine needle aspiration cytology. The smears were received in the department of pathology for cytological evaluation. Smears studied were highly cellular. The smears showed resemblance to anaplastic carcinoma of thyroid. The cells were present in a dispersed fashion. The tumor cells were highly pleomorphic with enlarged nucleus. The size of the nucleus was more than five times that of normal lymphocytes. The nuclei were highly pleomorphic and showed anisonucleosis. Hyperchromasia, uneven chromatin and conspicuous multiple nucleoli were also observed (Fig. 2, 3). Cytoplasm of the cells was abundant, thick and well-demarcated. Dense inflammatory infiltrate comprising predominantly of neutrophils, was present in the background. Discernible mitotic activity was observed in the slides. The tumour cells showed emperipolesis, where tumour cells were seen engulfing the neutrophils (FIG.4) Numerous multinucleated neoplastic giant cells were seen. Based on the above cytomorphological findings, a diagnosis of GCCL was made.

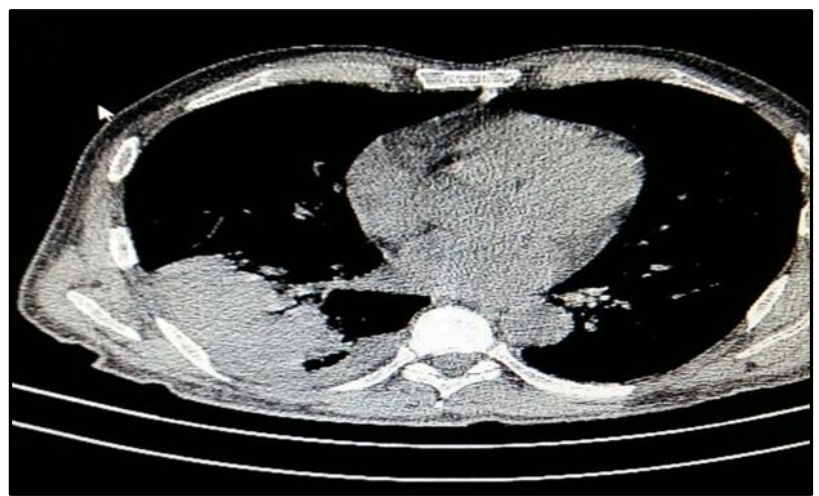

Figure 1. CT Scan showing - Solid lesion with peripheral enhancement in lower lobe of right lung with overlying rib destruction 


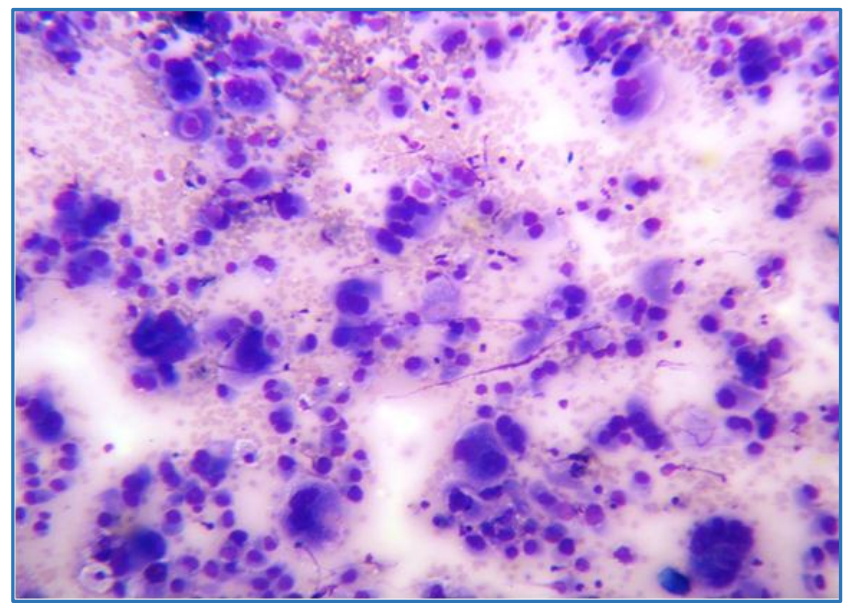

Figure 2. Giant cell carcinoma - multinucleated neoplastic giant cells (MGG, 10X10)

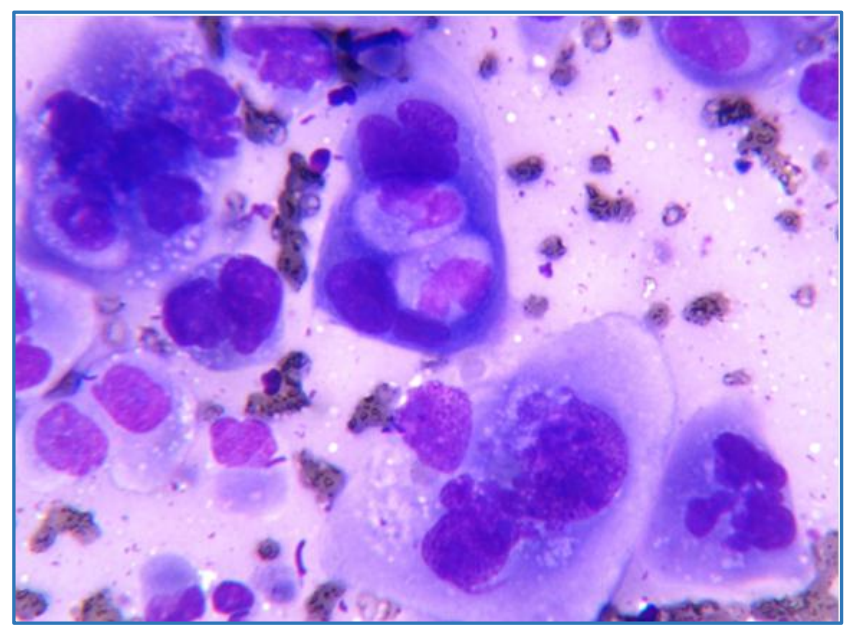

Figure 3. Giant cell carcinoma - multinucleated neoplastic giant cells (MGG, 10X40)

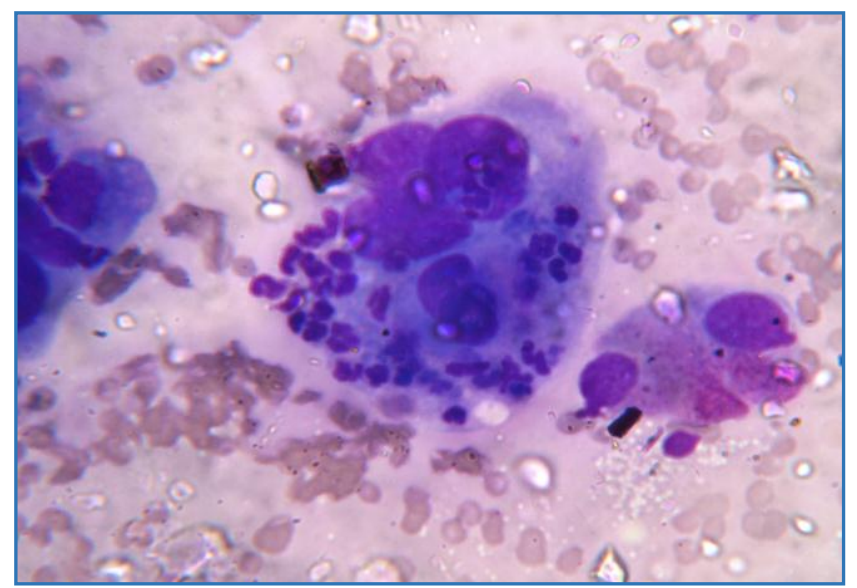

Figure 4. Showing emperipolesis, where large pleomorphic cells are seen to engulf the neutrophils. (MGG, 10X40)

\section{DISCUSSION}

According to 2015 WHO Classification of lung tumours, sarcomatoid carcinoma is a general term that includes pleomorphic carcinoma, carcinosarcoma and pulmonary blastema. For this reason, it is best to use the specific term for these entities whenever possible rather than the general term. This also may avoid confusion with a true sarcoma.
These tumours are rare accounting for less than $1 \%$ of all lung cancers. ${ }^{5}$ There has been mixed opinions in the literature regarding the entity Giant cell carcinoma. Addis et al. suggested that giant cell carcinoma arises by a process of dedifferentiation with eventual loss of epithelial markers showing unique ultrastructural features that support a diagnosis of giant cell carcinoma as a separate entity. This has to be differentiated from tumours which show giant cells as a component like different types of primary lung cancers (pleomorphic carcinoma, large cell carcinoma, squamous cell carcinoma etc.) as well as primary sarcomas, pleural mesotheliomas, pulmonary choriocarcinomas, metastatic tumours and after irradiation. ${ }^{4}$ Criteria for diagnosis of Giant cell carcinoma on cytology includes entire population of tumor giant cells, presence of neutrophils in the background, tumor giant cells showing emperipolesis. 6 According to Horn et al 'The term giant cell carcinoma is restricted to tumours in which multinucleated giant cells (greater than 40 microns) make up at least 10 percent of the neoplastic population'.? Though the tumor has predominant giant cell population studies found that there is no association between prognosis and extent of tumor giant cell formation. Herman et al opined that morphological criteria alone without the aid of histochemical techniques, the tumor giant cells of GCCL can be differentiated from giant cells of squamous cell carcinoma and large cell anaplastic carcinoma. ${ }^{8}$ Alasio et al felt that the diagnosis of Giant cell carcinoma should be kept in the differential when these features are present, but applied where it is clinically appropriate in the absence of histopathological confirmation. ${ }^{9}$ This tumor is more common in male smokers and is more common in the lung periphery. Pleomorphic carcinoma is a very close differential of giant cell carcinoma. Pleomorphic carcinoma is a undifferentiated non-small cell carcinoma that contain at least $10 \%$ of spindle cells and /or giant cells or a carcinoma consisting only of spindle and giant cells. Common clinical symptoms are cough, haemoptysis, and progressive dyspnoea or fever due to recurrent pneumonia. Incidental finding is very rare.10 Nevertheless, carcinomas of the lung with giant cells are characterized as having a more aggressive course compared to the other types lung carcinomas. Despite its historic association with poor outcomes, early-stage GCCL may be resected and followed serially with CT scans. Deangelis felt that though this is an aggressive tumor patients may survive for longer periods if the tumor is amenable for resection. ${ }^{11}$ In the present case cigarette smoking, male sex, site of the lesion and clinical presentation all correlated well with studies. FNAC of the lesion showed all the three features required to diagnose Giant cell carcinoma. According to Broderick specific diagnosis of giant cell carcinoma can be made if the required criteria are met. In our case, based on cytological finding, treatment was started but the patient could not withstand the treatment and condition of the patient became worse and ended in death within 3 months of initiation of therapy. Survival of the patients of giant cell carcinoma is short and ranged from 6-8 months and in our case, it is even earlier.

\section{CONCLUSION}

The cytological diagnosis of GCCL on aspiration has an appreciable impact on patient care because prognosis of this entity is poorer than other NSCLC, with high mortality rate. 
Presence of entire population of pleomorphic giant cells with characteristic emperipolesis on FNAC is diagnostic for giant cell carcinoma. Response to treatment is very poor and the outcome may be fatal.

\section{REFERENCES}

[1] Travis WD, Brambilla E, Nicholson AG, et al. The 2015 World Health Organization classification of lung tumors. J of Thoracic Oncology 2015;10(9):1243-60.

[2] Krishnamurthy A, Vijayalakshmi N, Majhi U. A fatal case of pure giant cell carcinoma of the lung. J Can Res Ther 2011;7(3):363-5.

[3] Kim TH, Kim SJ, Ryu YH, et al. Pleomorphic carcinoma of lung: comparison of CT features and pathologic findings. Radiology 2004;232(2):554-9.

[4] Parsa C, Orlando R, Naghdechi P, et al. Giant cell carcinoma of lung with aberrant cytoplasmic localizationof P63 protien. Global J Of Medical Research 2014;14(8-C).

[5] Yendamuri S, Caty L, Pine $M$, et al. Outcomes of sarcomatpoid carcinoma of the lung: a surveillance, epidemiology, and end results database analysis. Surgery 2012;152(3):397-402.
[6] Attanoos RL, Papagiannis A, Suttinont $P$, et al. Pulmonary giant cell carcinoma: pathological entity or ormorphological phenotype? Histopathology 1998;32(3):225-31.

[7] Broderick PA, Corvese NL, LaChance T, et al. Giant cell carcinomaof the lung: a cytologic evaluation. Acta Cytol 1975;19(3):225-30.

[8] Horn L, Pao W, Johnson DH. Chapter 89. Neoplasms of the LungHarrison's Principles of Internal Medicine. 18 ${ }^{\text {th }}$ edn. New York: McGraw-Hill.

[9] Alasio TM, Sun W, Yang GC. Giant cell carcinoma of the lung impact of diagnosis and review of cytological features. Diagn Cytopathol 2007;35(9):555-9.

[10] Kennedy A. Pathology and survival in operable cases of giant-cell carcinoma of the lung. J Clin Pathol 1969;22(3):354-60.

[11] Deangelis CE, Zarrow E, Sochan O. Giant cell carcinoma of the lung. Report of a case. Am Pract Dig Treat 1961;12:663-6. 